\title{
POTRET PEMBERDAYAAN SANTRI PADA PESANTREN DARUL MUKHLISIN KOTA KENDARI
}

\author{
Portrait of Student Empowerment \\ at Pondok Pesantren Darul Mukhlisin in Kendari
}

\author{
Asnandar Abubakar \\ Balai Penelitian dan Pengembangan Agama Makassar \\ Jl. A.P.Pettarani No. 72 Makassar \\ Email : asnandar@jurnalalqalam.or.id
}

\begin{abstract}
Abstrak
Penelitian ini dilakukan untuk melihat realitas eksistensi pesantren dan kegiatan pemberdayaan terhadap santri yang dilakukan oleh pesantren baik dari konsep, teknis, sampai pada hasil, sehingga diperoleh gambaran utuh tentang substansi pemberdayaan yang dilakukan oleh pesantren, dan untuk memperoleh gambaran tentang liku-liku yang dihadapi pesantren dalam pengembangan jenis kegiatan pemberdayaan yang dipilih oleh pesantren. Penelitian ini adalah penelitian kualitatif dengan menempatkan peneliti sebagai instrument utama. Data yang dihimpun adalah data primer dan data sekunder yang diperoleh melalui wawancara, observasi, serta dokumentasi. Pemberdayaan santri yang dilakukan di Pesantren Darul Mukhlisin yaitu koperasi, jahit menjahit, sapu ijuk, meubel atau pertukangan, dan las listrik. Tujuan pemberdayaan santri adalah untuk memberikan keterampilan dan mengembangkan kewirausahaan santri yang digunakan sebagai bekal ketika berada ditengah-tengah masyarakat. Manfaat dari usahausaha ekonomi yang dilakukan oleh pesantren adalah memberikan keuntungan kepada pesantren untuk menutupi biaya atau pengeluaran pesantren, juga menciptakan peluang usaha kepada masyarakat sekitar pesantren.
\end{abstract}

Kata kunci: pondok pesantren, pemberdayaan santri, kewirausahaan, Kendari

\begin{abstract}
This research was conducted to look at the reality of the existence of the boarding school and empowerment of students conducted boarding school by either of the concepts, technical, to the results, in order to obtain a complete picture of the substance carried by boarding school empowerment, and to gain an overview of the twists and turns encountered boarding school the development of type empowerment activities selected by the boarding school. This research is a qualitative study puts the researcher as the primary instrument. The data collected is primary data and secondary data obtained through interviews, observation, and documentation. Empowerment of students who performed at the Darul Mukhlisin there are cooperative, sewing, broom fibers, furniture or carpentry, welding and electrical. The aim is to empowering students to give skills and develop entrepreneurial students used as stock when in the midst of society. The benefits of economic enterprises undertaken by the boarding school is to provide benefits to boarding to cover boarding costs or expenses, as well as create business opportunities to the surrounding communities boarding.
\end{abstract}

Keyword : pondok pesantren, student empowering, entrepreneurship, kendari

\section{PENDAHULUAN}

$\mathrm{E}$ ksistensi pesantren dewasa ini telah mengalami transformasi baik dalam hal entitas pengembangan, pendalaman, dan menimbah ilmu-ilmu agama maupun pada aspek pengembangan bangunan dan sistem pendidikan. Begitupun fungsi pesantren yang sudah beradopsi sebagai agen perubahan di masyarakat ketika ada kesenjangan sosial terjadi seperti ketertinggalan, konflik, dan keterbatasan sumber daya serta penghambatan pembangunan ekonomi maka disitulah egilitarian pesantren hadir.

Dalam Mulkhan (2003:213) dijelaskan bahwa perjalanan politik nasional, pemerintahan Orde Baru telah berhasil mendorong perubahan citra politik kaum santri yang sebelumnya dikenal 
sebagai kaum oposan menjadi lebih akomodatif terhadap penguasa. Secara tidak langsung telah melahirkan transformasi persepsi terhadap kaum santri dalam realitas sosial. Bersamaan dengan itu dunia pesantren mengalami modernisasi kelembagaan yang antara lain berbentuk pendirian berbagai lembaga pendidikan formal, madrasah dan sekolah.

Seiring tantangan dan tuntutan dalam era globalisasi, maka pesantren harus mampu mendayagunakan segala potensi sumber daya insani termasuk didalamnya santri-santri untuk menggali sumber daya alam berdasarkan potensi daerah secara maksimal baik melalui penyerapan alih teknologi maupun dengan mengembangkan usahausaha ekonomi kreatif yang dapat memberdayakan santri ataupun masyarakat sekitar.

Program-program dan bantuan pemerintah terhadap dunia pendidikan di Negara kita terus meningkat sehingga juga berimplikasi pada pengembangan pesantren, pesantren harus mampu dan jeli memanfaatkan peluang yang ada dari pemerintah, sehingga pihak pengelola pesantren atau unsur manajemen dituntut untuk berkreasai dan inovatif menetapkan program-program kerja yang berorientasi kepada peningkatan pesantren, baik dalam hal sarana dan prasarana maupun dalam hal sistem dan metode pembelajaran.

Kementerian Agama melalui program vokasional yang bertujuan untuk pengembangkan keterampilan dan kewirausahaan santri serta mendidik santri agar memiliki tanggungjawab sosial, telah memberikan bantuan kebeberapa pesantren yang ada di Indonesia. Begitu juga Kementerian Perumahan Rakyat (Kemenpera) memberikan bantuan Rumah Susun Sederhana Sewa (Rusunawa) kepada pondok pesantren yang membutuhkannya. Dari Kementerian Pertanian memberikan bantuan kepada pondok-pondok pesantren untuk mengembangkan usaha ternak maupun agribisnis. Selain bantuan langsung dari pemerintah juga ada bantuan dari luar negeri yaitu contohnya dari Negara Australia melalui programnya di sektor pendidikan, yang bertujuan untuk membantu Indonesia mencapai program wajib belajar 9 tahun pada 2015. Lewat bantuan tersebut Australia berkomitmen membangun lebih dari 2000 sekolah terutama sekolah Islam Madrasah dan Pondok Pesantren.

Meskipun pemerintah sudah membuka peluang kepada pesantren untuk memanfaatkan program-program yang ada, tetapi ada juga pesantren yang membutuhkan yang tidak tersentuh oleh program dan bantuan dari pemerintah. Olehnya pengelola pesantren menyiasati dengan membuka usaha-usaha ekonomi untuk menutupi kebutuhan-kebutuhan rutin dan biaya-biaya yang dikeluarkan dalam mengelola pesantren. Usaha ini dilaksanakan dengan memberdayakan santri agar dapat menghemat biaya dan mendidik santri agar mempunyai keterampilan sebagai bekal ketika sudah terjun ke masyarakat.

Penelitan tentang pemberdayaan santri di pesantren perlu dilakukan untuk melihat realitas usaha pesantren dalam menjalankan perekonomian dengan memamfaatkan santri dan gambaran yang lebih luas tentang konsep pemberdayaan santri di pesantren, penelitian ini diharapkan bukan hanya sekedar memotret dari sudut penguatan ekonomi pesantren atau skill santri. Konsep pemberdayaan diharapkan tidak terlepas dari kekhasan pesantren mengelola pendidikan keagamaan sehingga menjadi kekayaan informasi dan data bagi Kementerian Agama dalam penguatan peran dan pemberdayaan pesantren ke depan.

Masalah yang diangkat dalam penelitian ini adalah bagaimana gambaran realitas eksistensi pesantren dan upaya pemberdayaan santri yang dilakukan di pesantren, dan bagaimana peluang dan tantangan yang dihadapi pesantren dalam pemberdayaan santri. Dan tujuannya adalah untuk mencermati eksistensi pesantren dan kegiatan pemberdayaan terhadap santri yang dilakukan oleh pesantren baik dari konsep, teknis, sampai pada hasil, sehingga diperoleh gambaran utuh tentang substansi pemberdayaan yang dilakukan oleh pesantren, dan untuk memperoleh gambaran tentang liku-liku yang dihadapi pesantren dalam pengembangan jenis kegiatan pemberdayaan yang dipilih oleh pesantren untuk menemukan langkah selektif terhadap problem pemberdayaan dan pengembangan terhadap prospeknya.

\section{Tinjauan Pustaka \\ Pesantren}

Dalam Peraturan Pemerintah nomor 55 tahun 2007, tentang pendidikan Agama dan Pendidikan Keagamaan pasal 1 ayat (4) disebutkan bahwa pesantren atau pondok pesantren adalah lembaga pendidikan keagamaan Islam berbasis masyarakat yang menyelenggarakan pendidikan diniyah atau secara terpadu dengan jenis pendidikan lainnya. Lanjut pada Bab III pasal 26 yakni pesantren menyelenggarakan pendidikan dengan tujuan 
menanamkan keimanan dan ketakwaan kepada Allah SWT, akhlak mulia, serta tradisi pesantren untuk mengembangkan kemampuan, pengetahuan, dan keterampilan peserta didik untuk menjadi ahli ilmu agama Islam (mutafaqqih fiddin) dan/ atau menjadi muslim yang memiliki keterampilan/ keahlian untuk membangun kehidupan yang islami di tengah-tengah masyarakat.

Pada Peraturan Menteri Agama Nomor 13 tahun 2014 tesebut Bab III pasal 5 menyebutkan pesantren wajib memiliki (a) Kiyai atau sebutan lain sejenis; (b) santri; (c) Pondok atau asrama pesantren; (d) Masjid atau Mushollah; (e) Pengajian dan Kajian Kitab Kuning atau dirasah Islamiyah dengan pola pendidikan mu'allimin.

Suatu lembaga pendidikan dapat dikatakan sebagai pesantren jika memilikii persyaratanpersyaratan tertentu atau elemen-elemen pokok. Dhofier (1984) dalam Daulay (2012:19) menyebutkan ada lima elemen-elemen pokok pesantren, yaitu: pondok, mesjid, santri, pengajaran kitab-kitab klasik, dan kyai.

Tujuan pendidikan pesantren adalah menciptakan dan mengembangkan kepribadian muslim, yaitu kepribadian yang beriman dan bertakwa kepada Tuhan, berakhlak mulia, bermanfaat bagi masyarakat atau berhikmad kepada masyarakat dengan jalan menjadi kawula atau abdi masyarakat yang bersifat rasul, yaitu menjadi pelayan masyarakat sebagaimana kepribadian Nabi Muhammad (mengikuti sunnah Nabi), mampu berdiri sendiri, bebas, dan teguh dalam kepribadian, menyebarkan agama atau menegakkan Islam dan kejayaan umat di tengah-tengah masyarakat (' $\mathrm{Izz}$ alIslam wa al-Muslimin) dan mencintai ilmu dalam rangka mengembangkan kepribadian manusia. (Mastuhu dalam Qomar, 2005:4).

Tujuan umum pesantren adalah memberikan pembinaan terhadap warga Negara agar berkepribadian muslim sesuai dengan ajaran-ajaran agama Islam dan menanamkan rasa keagamaan tersebut pada semua aspek-aspek kehidupan, dan menjadikannya sebagai orang yang berguna bagi agama, masyarakat, dan Negara.

\section{Fungsi dan Peranan Pesantren}

Laporan Syarif dkk. (dalam Qomar, 2005:22) menyebutkan bahwa pada masa awal mulanya berdirinya pesantren (masa Syekh Maulana Malik Ibrahim) berfungsi sebagai pusat pendidikan dan penyiaran agama Islam. Pendidikan dapat dijadikan bekal dalam mengumandangkan dakwah, sedang dakwah dapat dimanfaatkan sebagai sarana dalam membangun sistem pendidikan. Menurut Ma'shum (dalam Qomar, 2005:23) bahwa fungsi pesantren mencakup tiga aspek yaitu fungsi religious (diniyyah), fungsi sosial (ijtimaiyyah), dan fungsi edukasi (tarbawiyyah). Menurut A.Wahid Zaini bahwa disamping sebagai lembaga pendidikan, pesantren juga berfungsi sebagai lembaga pembinaan moral dan kultural, baik dikalangan para santri maupun santri dengan masyarakat. Kedudukan ini memberikan isyarat bahwa penyelenggaraan keadilan sosial melalu pesantren lebih banyak menggunakan pendekatan kultural.

Olehnya fungsi dan peranan pesantren dapat dijelaskan sebagai pusat pendidikan yang berbasis agama Islam, pembinaan akhlak dan moral, serta sebagai tempat penyiaran agama Islam dengan memperhatikan budaya dan struktur nilai sosial mayarakat.

Tiga fungsi strategis pesantren, yakni pertama, sebagai pusat pengkaderan dan pencetak pemikirpemikir agama/ulama (center of excellent), kedua sebagai lembaga pencetak sumber daya manusia handal (human resources) dan ketiga sebagai lembaga yang memiliki kekuatan melakukan pemberdayaan pada masyarakat (community empowerment). (Ahmad Nunu dkk, 2010:236-237).

\section{Kategorisasi pesantren}

Bentuk dan kekhasan suatu pesantren dipengaruhi oleh karakter dan usaha mandiri dari kiai atau Pembina pesantren, yang tentunya dibantu santri dan masyarakat. Dalam Qomar (2005:1617) berbagai pendapat tentang pengelompokan pesantren. Yaitu diantaranya, dari segi kurikulum, Arifin menggolongkan menjadi pesantren modern, pesantren tahassus (tahassus ilmu alat, ilmu fiqh/ ushul fiqh, ilmu tafsir/hadits, ilmu tasawuf/thariqat, qiraat Alquran), dan pesantren campuran.

Dhofier (masih dalam Qomar, 2005) membagi pesantren menjadi dua kategori yaitu pesantren salafi dan khalafi. Pesantren salafi tetap mengajarkan kitab-kitab Islam klasik sebagai inti pendidikannya. Penerapan sistem madrasah untuk memudahkan sistem sorogan yang dipakai dalam lembaga-lembaga pengajian bentuk lama, tanpa mengenalkan pengajaran pengetahuan umum, sedangkan pesantren khalafi telah memasukkan pelajaran-pelajaran umum dalam madrasahmadrasah yang dikembangkan atau membuka tipe-tipe sekolah umum di dalam lingkungan pesantren. 
Pesantren juga dibagi berdasarkan sistem pendidikan yang dikembangkan, yaitu: (1) pesantren yang memiliki santri yang belajar dan tinggal bersama kiai, kurikulum tergantung kiai, dan pengajaran secara individual. (2) pesantren yang memiliki madrasah, kurikulum tertentu, pengajaran bersifat aplikasi, kiai memberikan pelajaran secara umum dalam waktu tertentu, santri bertempat tinggal di asrama untuk mempelajari pengetahuan agama dan umum. Dan (3) pesantren hanya berupa asrama, santri belajar di sekolah, madrasah, bahkan perguruan tinggi umum atau agama di luar, kiai sebagai pengawas dan pembina mental.

\section{Santri}

Santri adalah siswa yang belajar di pesantren dan digolongkan pada dua kelompok, yaitu : (1) santri mukim, yaitu santri yang berdatangan dari tempat-tempat jauh yang tidak memungkinkan dia untuk pulang ke rumahnya, maka dia harus mondok (tinggal) di pesantren. Sebagai santri mukim mereka memiliki kewajiban-kewajiban tertentu, (2) santri kalong, yaitu siswa-siswa yang berasal dari daerah sekitar pesantren yang memungkinkan mereka pulang ke tempat kediaman masing-masing. Santri kalong ini smengikuti pelajaran dengan cara pulang pergi ke pesantren. (Daulay, 2012:21).

Dalam Mulkhan (2003:213) kosa kata santri dipakai bagi sebutan orang yang belajar di pondok pesantren dan pemeluk Islam yang taat menjalankan aturan ibadah dan ajaran agama Islam lainnya.

Pemberdayaan santri dilakukan dengan membekali sejumlah keahlian tertentu sesuai dengan program pesantren. Santri yang diberdayakan di pesantren adalah santri yang masih aktif menempuh pembelajaran dan santri alumni. Bagi santri alumni jenis pemberdayaan yang melibatkan mereka, adalah jenis pemberdayaan yang dapat membantu pengembangan pesantren. Merupakan sebuah keharusan bagi pesantren membekali santrinya dengan keterampilan agar mempunyai modal tambahan ketika kelak terjun di tengah-tengah masyarakat.

\section{METODE}

Penelitian dilakukan di Pesantren Darul Mukhlisin Kota Kendari. Penentuan kabupaten/ kota dilakukan setelah penjajakan. Penelitian ini adalah penelitian kualitatif dengan menempatkan peneliti sebagai instrument utama. Oleh karena itu, kejelian dan ketekunan peneliti dalam pengumpulan data sangat diperlukan terhadap autentik dan objektivitas data.
Data yang ditelusuri dalam penelitian ini meliputi data primer dan data sekunder. Untuk memperoleh data tersebut, data primer digali dari pimpinan pondok atau Pembina kegiatan pemberdayaan, santri, mitra kerja dan atau pengguna hasil pemberdayaan, sedangkan data sekunder digali dan instansi/pejabat/organisasi terkait.

Pengumpulan data dilakukan dengan kegiatan wawancara terhadap sumber-sumber pendapat terkait, baik pada pesantren tempat unit analisis berada, maupun pada unsur pejabat terkait di kementerian agama, tokoh masyarakat atau pelaku usaha kegiatan yang jadi mitra pesantren. Untuk terarahnya wawancara dibuatkan pedoman wawancara sebagai alat bantu. Wawancara adalah teknik mengumpulkan data yang akurat untuk keperluan proses pemecahan masalah tertentu, yang sesuai dengan data. Pencarian data dilakukan dengan tanyajawab secara lisan dan bertatap muka langsung. (Muhamad, 2008:151).

Kemudian dilakuakan observasi untuk mengetahui realitas kegiatan pemberdayaan yang dilakukan di pesantren sasaran penelitian, maka peneliti mencermati aktivitas pemberdayaan yang dilakukan di pesantren dengan terjun langsung pada sentra-sentra kegiatan. Peneliti mengidentifikasi bahan, proses dan hasil. Agar terarah kegiatan observasi dipandu oleh pedoman observasi. Dan selanjutnya dilakukan dokumentasi, yang dimaksudkan sebagai upaya pencatatan, perekaman terhadap aspek-aspek yang bersifat keadministrasian terhadap hal-hal terkait dengan penelitian. Pendokumentasian itu dilakukan di sasaran ataupun lembaga lain yang dianggap memiliki keterkaitan data yang diperlukan dengan sasaran penelitian sebagai pendukung kelengkapan data yang diperlukan, juga terhadap sumbersumber referensi terkait.

\section{PEMBAHASAN \\ Profil Pesantren Darul Mukhlisin}

Pondok Pesantren Darul Mukhlisin berdiri pada tanggal 22 Juni 2007 Masehi, berdasarkan Akta Notaris Atas Keputusan Menteri Hukum dan Hak Asasi Manusia Republik Indonesia, beralamat di jalan Budi Utomo nomor 34 Kelurahan Kadia Kecamatan Kadia Kota Kendari Sulawesi Tenggara. Pesantren ini dibangun di atas tanah wakaf saudara Jamaludin, S.Ag. Pada awalnya pesantren memiliki luas 3.000. meter persegi, namun seiring dengan perkembangannya dan kegigihan pengurus 
mengelolah dan mengembangkan pesantren, hingga saat ini sudah memiliki areal sekitar satu hektar, dan kesemuanya diwakafkan untuk pesantren Darul Mukhlisin.

Pesantren ini dinamakan Darul Mukhlisin atas saran sendiri oleh Bapak Jamaludin, S.Ag. Yang Artinya tempatnya orang-orang yang Ikhlas. Alasan pengurus memilih nama ini, pertama, pendiri Pondok berniat mudah-mudahan dengan dasar keikhlasan pondok pesantren ini dapat memperoleh berkah dan rahmat dari Allah Swt. Yang kedua, alasan beliau memilih nama ini karena sejak awal tempat belajar santriwan dan santriwati penuh dengan kesederhanaan dengan bangunan semi permanen yang beratapkan rumbia dan berdindingkan papan yang murah. Asrama santriwan berukuran 16 X 6 $\mathrm{m} 2$ dan asrama santriwati berukuran $9 \times 7 \mathrm{~m} 2$.

Jumlah Santri Pondok Pesantren Darul Mukhlisin pada tahun ajaran 2011/2012 sebanyak 124 santri yang terbagi atas 75 santriwan dan 49 santriwati. Pada tahun ajaran 2012/2013 jumlah santri meningkat menjadi 150 santri yang terbagi atas 58 santriwan dan 92 santriwati, dan pada tahun ajaran 2013/2014 meningkat lagi menjadi 225 santri yang terbagi atas 102 santriwan dan 123 santriwati. Tenaga pengasuh atau pengajar Pondok Pesantren Pesantren Darul Mukhlisin adalah guru-guru yang mengajar dipondok yang berjumlah sebanyak 20 orang.

\section{Pemberdayaan Santri Pesantren Darul Mukhlisin}

Pemberdayaan santri yang dilakukan di Pesantren Darul Mukhlisin ada empat jenis pemberdayaan yaitu koperasi, jahit menjahit, sapu ijuk, meubel atau pertukangan, dan las listrik. Proses pemberdayaan dilakukan tanpa mengesampingkan tugas dan fungsi pesantren yaitu tetap memberikan pendidikan ilmu agama kepada santri sembari memberikan keterampilan berdasarkan prinsipprinsip islami.

Daulay (2012) mengungkakan tiga " $H$ " dalam mendidik santri sekarang ini, yaitu: (1) head, artinya kepala, maknanya mengisi otak santri dengan ilmu pengetahuan. Sebagai salah satu lembaga pendidikan maka pesantren tidak terlepas dari fungsinya, yaitu memberikan pengetahuan kepada santri sebagai wujud dari nilai-nilai tujuan bangsa yaitu mengangkat harkat dan martabat masyarakat Indonesia. (2) heart, artinya hati, maknanya mengisi hati santri dengan iman dan takwa. Dengan materi pelajaran agama sebagai dasar pembelajaran di pesantren, maka secara tidak langsung santri dibekali nilai-nilai islami dalam memaknai hidup sehingga santri diharapkan mampu menghayati dan mengamalkan nilai-nilai agama dalam kehidupan sehari-hari. (3) hand, artinya tangan, maknanya memberikan pendidikan keterampilan kepada santri. Dengan membekali keterampilan kepada santri, maka santri mempunyai modal yang kuat ketika telah berada ditengah-tengah masyarakat.

Pendidikan keterampilan yang diberikan kepada santri bertujuan untuk memberikan modal dasar pengetahuan dibidang usaha sebagai bekal untuk mengembangkannya ketika sudah berinteraksi pada kehidupan luar pesantren atau sudah berada ditengah-tangah masyarakat. Bekal keterampilan ini dapat digunakan untuk membuka usaha baru atau membantu mengembangkan usaha orang lain sesuai dengan kompetensi keterampilan yang dimilikinya.

Keterampilan yang berkembang di pesantren tidak terlepas dari falsafah berdirinya pesantren, yaitu kemandirian. Pesantren sebagai lembaga pendididikan agama Islam dikenal sebagai lembaga pendidikan yang paling mandiri, baik dari awal berdirinya maupun sampai sekarang, meskipun saat ini sudah banyak pesantren yang mendapat perhatian dari pemerintah dengan mendapat bantuan-bantuan dari program yang diluncurkan pemerintah.

Kemandirian ini senantiasa disadari oleh kiai atau pimpinan pesantren, sehingga secara tidak langsung juga menanamkan nilai-nilai mandri kepada santri. Kemandirian ini menjadi salah satu modal santri untuk berkiprah di masyarakat, tetapi modal tersebut belum cukup bila tidak dibarengi dengan potensi. Olehnya kiai atau pimpinan pondok memandang perlu untuk menggali potensi diri santri dengan memberikan pelajaran keterampilan. Tujuannya adalah memberikan bekal kepada santri agar mampu hidup secara mandri di tengah-tengah masyarkat, dan juga untuk membuka cakrawala dan wawasan berpikir keduniaan santri. (Qomar, 2005:134)

Selain sebagai salah satu dasar pengembangan keterampilan, kemandirian pesantren juga merupakan bekal dan elemen penting yang digunakan sebagai potensi untuk mewujudkan masyarakat sipil sebagai pilar demokrasi. Dengan kemandirian, pesantren memilikim keteguhan dalam merespon arus perubahan sosial, sehingga pesantren akan mudah mengambil peran yang strategis dalam proses pemberdayaan sosial. Dengan 
menggunakan jaringan alumninya, pesantren memiliki peluang untuk mengembangkan potensi yang dimilikinya, baik keilmuan maupun ekonomi. (Abd.Muin,dkk., 2007:27).

Keterampilan yang diberikan kepada santri tentu didasari dengan ilmu pengetahuan yang bersifat islami, sehingga santri tidak menambrak norma-norma dan nilai-nilai kehidupan. Keterampilan yang dimiliki santri dapat berguna untuk kepentingan masyarakat atau hajat hidup orang banyak, tidak untuk dimanfaatkan kepada hal-hal yang dapat mengganggu kehidupan manusia atau diluar ajaran-ajaran yang islami.

Begitupun keterampilan yang dikembangkan di pesantren Darul Mukhlisin, adalah keterampilan yang dapat memberikan peluang kepada santri untuk membuka usaha, atau keterampilan yang ada hubungannya dengan kewirausahaan. Keterampilan ini dilaksanakan sebagai kegiatan ekstrakurikuler santri, sehingga memberikan peluang kepada pesantren untuk mengatur waktu pembelajaran santri.

Selain mengacu pada prinsip-prinsip yang islami, pesantren Darul Mukhlisin dalam menjalankan usaha juga mengacu pada ilmu ekonomi yang berlandaskan Islam. Ekonomi yang islami ini, tidak memonopoli keuntungan dan kebutuhan-kebutuhan masyarakat. Yang terpenting adalah sifat pemerataan, sehingga keuntungan yang diperoleh dapat dirasakan mamfaatnya oleh semua pihak baik santri, pesantren, maupun masyarakat. salah satunya adalah sebagian bahan-bahan pokok yang didapatkan Pesantren Darul Mukhlisin dibagikan kepada warga yang kurang mampu di sekitar pesantren.

Ekonomi yang islami berusaha mewujudkan kesejahteraan tidak saja pada pelaku ekonominya tetapi juga pada masyarakat secara umum. Ekonomi Islam adalah ilmu yang mempelajari usaha manusia untuk mengalokasikan dan mengelola sumber daya untuk mencapai falah berdasarkan pada prinsipprinsip dan nilai-nilai Alquran dan Sunnah. (Pusat Pengkajian dan Pengembangan Ekonomi Islam, P3EI, 2008:19).

Dalam Muhamad (2008:6) ilmu ekonomi Islam adalah studi tentang bagaimana individu atau masyarakat memilih dan menggunakan sumber daya yang ada, sekarang atau yang telah ditinggalkan oleh generasi masa lalu, sesuai aturan atau syarak ( Alquran, hadits, atau hukum dibawahnya) yang digunakan untuk memenuhi kebutuhan jasmani dan rohani tanpa adanya eksploitasi sehingga dapat mewujudkan falah (kesejahteraan) bagi individu maupun masyarakat. Dalam P3EI (2008:2) Falah berarti kesuksesan, kemuliaan, atau kemenangan. Untuk kehidupan dunia, falah berarti kelangsungan hidup, kebebasan berkeinginan, serta kekuatan dan keormatan. Sedang untuk kehidupan akhirat, falah berarti kelangsungan hidup yang abadi, kesejahteraan abadi, kemuliaan abadi dan pengetahuan yang abadi.

Usaha-usaha yang dilakukan oleh pesantren Darul Mukhlisin dapat memberikan kesejahteraan baik oleh santri sendiri maupun kesejahteraan masyarakat sekitar karena setidaknya usaha tersebut memberikan keuntungan. Lanjut dalam P3EI (2008:2-3) kesejahteraan menurut ajaran Islam adalah kesejahteraan holistik dan seimbang, yaitu kecukupan materi yang didukung oleh terpenuhinya kebutuhan spiritual serta mencakup individu dan sosial, dan kesejahteraan di dunia dan di akhirat, kecukupan materi di dunia ditunjukkan dalam rangka untuk memperoleh kecukupan di akhirat.

\section{Koperasi}

Koperasi dijalankan oleh santri yaitu santri yang mendapat kepercayaan dari pimpinan pondok. Tugas santri ini adalah menjual barang-barang yang disediakan oleh koperasi seperti sembako, alat tulis santri, dan kebutuhan santri lainnya seperti sandal dan pakaian dalam. Selain menjalankan aktivitas penjualan di koperasi, santri juga mendapat tugas menyediakan bahan-bahan kebutuhan santri tersebut di atas atau membeli dari luar yaitu di pasar-pasar utama di Kota Kendari seperti di Pasar Mandonga dan juga di toko-toko distributor bahanbahan pokok.

Dalam mengelola koperasi santri ini diawasi oleh pendamping yaitu alumni pesantren yang mendapat kepercayaan dari pimpinan pondok. Koperasi sangat membantu bagi para santri untuk mengembangakan potensinya dalam bidang ekonomi dan sebagai latihan bertanggung jawab dan kemandirian santri. Hasil dari keuntungan koperasi ini akan digunakan untuk pengembangan pesantren.

Tujuan dibentuknya koperasi santri ini adalah untuk:

- Menciptakan usaha kreatif dari santri

- Membantu penyediaan kebutuhan pokok santri secara khusus dan pesantren secara umum

- Membantu mengembangkan dan menggali potensi santri dalam berusaha dibidang 
ekonomi.

- Menumbuhkan sikap tanggungjawab, serta kepercayaan dan kemandirian santri

- Melatih santri berwirausaha dalam bidang perdagangan

- Mendukung program pesantren, santri dapat memanfaatkan waktu secara efesien dalam belajar, tidak perlu keluar pesantren untuk membeli kebutuhan pokok

- Meminimalisir waktu santri untuk memenuhi kebutuhan pokok.

- Keuntungan dari usaha ini sebagian digunakan kembali untuk memenuhi kebutuhuan makanan sehari-hari santri.

\section{Jahit Menjahit}

Usaha konveksi (jahit menjahit) dijalankan dengan melibatkan santri secara langsung, yaitu dengan mengajarkan santri cara menjahit, yaitu mulai dengan cara mengukur pakaian, membuat pola, kemudian cara menggunakan mesin jahit dan selanjutnya cara menjahit. Santri yang dilibatkan pada usaha konveksi ini adalah santriwati yang telah duduk di kelas 11 dan kelas 12 madrasah aliyah dan sekolah menengah kejuruan (SMK) Busana yang berada dibawah naungan Yayasan Darul Mukhlisin.

Jahitan yang dikerjakan oleh santri adalah seragam sekolah seperti kemeja putih, rok atau celana panjang biru dan abu-abu, serta pakaian batik. Usaha konveksi ini sangat membantu pondok pesantren karena baju-baju santri sudah bisa disediakan sendiri tanpa harus membeli lagi dari luar yang tentunya akan membutuhkan biaya yang tidak sedikit.

Manfaat yang didapatkan pesantren dari usaha jahit menjahit ini adalah:

Dapat menutupi biaya yang dikeluarkan santri ataupun pesantren dalam melengkapi seragam sekolahnya. Dengan menjahit sendiri pakaian di pesantren maka tidak mengeluarkan lagi biaya untuk ongkos menjahit.

Mengembangkan kewirausahaan santri dalam hal usaha konveksi.

Memberikan keterampilan jahit menjahit bagi santri

Menciptakan peluang usaha bagi pesantren sendiri, santri, dan juga masyarakat sekitar pesantren.

\section{Usaha Sapu Ijuk}

Usaha ini dimulai sejak tahun 2009 pada saat pesantren mendapatkan bantuan dari Kanwil Kementerian Agama Provinsi Sulawesi Tenggara sebesar 100 juta rupiah. Dengan bantuan dana ini pihak pesantren mengembangkan pembuatan sapu ijuk yang merupakan salah satu usaha ekonomi dengan melibatkan santri. Santri-santri yang dilibatkan dalam pembuatan sapu ijuk ini adalah santri yang telah duduk di kelas 10, 11, dan 12 atau santri yang belajar pada jenjang madrasah aliyah. Alasan pelibatan santri tingkat madrasah aliyah ini karena mereka sudah memenuhi standar pengerjaan sapu ijuk seperti penataan ijuk pada tempat tatanan yang terbuat dari plastik yang membutuhkan tarikan yang agak kuat.

Bahan-bahan sapu ijuk ini diantaranya adalah ijuk, tatanan ijuk dari plastic, dan tongkat kayu. Bahan ijuk diambil dari petani ijuk di Raha Kabupaten Muna, sedangkat tatanan ijuk dari plastic dipesan dari Surabaya, dan tongkat kayu dibuat sendiri di pondok pesantren. Sapu ijuk ini dipasarkan di masyarakat sekitar pondok pesantren dan sebagian dibawah ke toko-toko penjual bahan rumah tangga. Ijuk adalah bahan serat alami yang di dapat dari pohon (enau/aren/nira) sebuah pohon yang sejenis palm ini mampu menghasilkan beberapa jenis bahan yang sangat berguna bagi kelangsungan hidup manusia, di antaranya serabut yang berupa serat yang di sebut ijuk.

Manfaaat dari usaha sapu ijuk ini adalah:

Meransang keinginan masyarakat untuk berwirausaha khususnya pembuatan sapu ijuk.

Memberikan keterampilan kepada santri dalam pembuatan sapu ijuk

Memberikan keuntungan kepada santri dan pesantren sehingga dapat meringankan biaya pendidikan

Membantu masyarakat sekitar pesantren dalam memenuhi salah satu kebutuhan rumah tangga.

Mengembangkan usaha ekonomi kerakyatan dengan memanfaatkan potensi daerah.

\section{Pertukangan dan Las Listrik}

Usaha pertukangan atau meubel dijalankan untuk memenuhi kebutuhan meja-meja dan kursikursi pondok pesantren seperti kantor dan ruang belajar. Pembuatan meja ini dikerjakan oleh santri 
dan masyakat sekitar pondok pesantren. Santri yang dilibatkan pada pembuatan meja ini adalah santri yang sebelumnya telah dimagangkan di Balai Latihan Kerja (BLK) Kota Kendari. Proses pemagangan ini berlangsung selama sebulan sesuai dengan struktur program belajar yang ditetapkan oleh BLK. Santri yang telah dimagangkan ini kemudian mengembangkan ilmunya langsung ke pembuatan meja dan juga mengajarkan kepada santri-santri lainnya.

Usaha Las Listrik di pesantren Darul Mukhlisin dijalankan untuk memenuhi kebutuhan rumah tangga pondok pesantren seperti pagar bangunan dan pengaman jendela. Las listrik ini juga dijalankan oleh santri yang sebelumnya dimagangkan di BLK Kota Kendari. Pesantren juga bisa menerima pesanan dari masyarakat apabila ada yang ingin dibuatkan pagar atau pengaman jendela.

Manfaat dari usaha pertukangan dan las listrik ini adalah:

- Membantu pihak pengelolah pesantren dalam memenuhi kelayakan sarana dan prasana pesantren.

- Dapat memenuhi perlengkapan meubel (meja) kantor pesantren Darul Mukhlisin.

- Memberikan keterampilan kepada santri untuk membuat meja, kursi, dan perlengkapan ruang kelas atau kantor pesantren yang terbuat dari kayu seperti lemari.

- Memberikan keterampilan kepada santri dalam bidang las listrik sehingga dapat membuat pengamanan jendela dan pagar pesantren.

- Memberikan pengetahuan kepada santri untuk berwirausaha dalam bidang pertukangan dan las listrik.

\section{Peluang dan Tantangan}

Tujuan pemerintah dalam mengembangkan life skill (kecakapan hidup) di pesantren adalah sebagai bekal kecakapan santri ketika sudah tamat di pesantren untuk mengembangkan diri di lingkungan masyarakat. Kecakapan ini dapat berbentuk soft skill yaitu keterampilan seseorang dalam berhubungan dan bekerjasama dengan orang lain, dan hard skillI yaitu penguasaan ilmu pengetahuan, teknologi, dan keterampilan yang berhubungan dengan bidang ilmunya.

Peluang untuk mengembangkan soft skill pada pesantren Darul Mukhlisin sangat terbuka, santrisantri pondok pesantren Darul Mukhlisin banyak diundang pada acara-acara sosial keagamaan seperti ketika ada warga masyarakat sekitar pesantren yang mengadakan hajatan baik pengantin, sunatan atau aqiqah anak, santri diundang untuk mengaji atau barzandji. Biasa juga ada warga masyarakat yang mengadakan aqiqah untuk anaknya menyerahkan ke pihak pesantren untuk segala urusan yang berhubungan dengan aqiqah seperti untuk makanannya. Kambing tinggal dibawah ke pondok kemudian santri-santri yang memasak. Pada bulan ramadhan, banyak santri yang mendapat panggilan untuk dkontrak menjadi imam mesjid selama bulan ramadhan, selain jadi imam mesjid banyak juga menjadi imam shalat Idul Fitri dan Idul Adha.

Kendala-kendala yang dihadapi oleh pondok pesantren ketika menerima bantuan baik berupa uang atau barang adalah kurangnya tenaga ahli yang sesuai dengan jenis bantuan yang diterimanya. Pondok pesantren harus didampingi dan dibina oleh tenaga ahli ketika mendapat bantuan life skill, karena banyak bantuan berupa alat keterampilan hanya tinggal saja karena tidak digunakan berhubung tidak ada yang mengetahui pengoperasiannya.

Kementerian Agama biasanya memberikan bantuan pembinaan dalam bentuk uang sedangkan instansi lain dalam bentuk barang. Kementerian Agama hanya menfasilitasi ketika ada bantuan dari instansi pemerintah atau lembaga lain, seperti dari Dinas Koperasi, Dinas perindag, dinas pertanian, Dinas Pertanian, dan Dinas Kesehatan. Pondok Pesantren harus lebih kreatif dan berhubungan langsung dengan instansi yang memberikan bantuan. Olehnya pengelola pesantren dituntut untuk memanfaatkan bantuan tersebut agar dapat digunakan secara maksimal, efesien dan efektif.

Dalam konteks Sulawesi Tenggara, pondok pesantren memiliki konstribusi positif dalam membangun moralitas dan religionositas. Selain itu output pendidikan pondok pesantren menyediakan tenaga-tenaga muda yang memiliki pengetahuan agama mendalam dan keterampilan yang dapat membantu mengembangkan perekonomian daerah. Selain itu output pendidikan pondok pesantren menyediakan tenaga-tenaga muda yang memiliki pengetahuan agama mendalamndan keterampilan yang dapat membantu mengembangkan masyarakat Sulawesi Tenggara. (Suprianto, dkk, 2011).

\section{PENUTUP}

Pemberdayaan santri di Pesantren Darul Mukhlisin mempunyai tiga manfaat yaitu: Pertama untuk santri; Kedua untuk pesantren dan manfaat; Ketiga adalah untuk masyarakat. Manfaat yang diharapkan untuk santri adalah dengan adanya 
pemberdayaan ini akan dapat mengembangkan keterampilan dan memberikan dasar kewirausahaan kepada santi, serta memberikan bekal kepada santri ketika sudah terjun ditengah-tengah masyarakat. Sedangkan manfaat untuk pesantren adalah dapat memberikan keuntungan yang digunakan untuk menutupi pengeluaran seperti biaya untuk pakaian santri, menutupi biaya untuk kebutuhan seharihari seperti makan, dan juga menutupi biaya untuk memperbaiki sarana dan prasarana pesantren. Manfaat untuk masyarakat adalah menumbuhkan roda perekonomian sekitar pesantren dan menciptakan peluang usaha kepada masyarakat untuk turut serta mengembangkan potensi ekonomi seperti pembuatan sapu ijuk, dan jahit menjahit, serta pertukangan dan las.

Peluang menciptakan usaha ekonomi untuk pemberdayaan santri dilakukan karena dua alasan yaitu (1) terbukanya peluang pesantren untuk memanfaatkan program-program dan bantuan pemerintah dalam memajukan dunia pendidikan termasuk pengembangan pesantren. Banyak program-program yang ditawarkan oleh pemerintah seperti bidang agrobisnis, perdagangan, peternakan, usaha konveksi, dan usaha-usaha ekonomi lainnya. (2) adanya usaha yang kreatif dan inovatif dari pihak pengelola pesantren untuk menciptakan peluang usahan terhadap santri dalam rangka memenuhi kebutuhan rutin pesantren dan untuk mendapatkan keuntungan yang digunakan menutupi pengeluaran-pengeluaran yang membutuhkan biaya seperti perbaikan sarana dan prasarana.

Perlunya kerjasama semua pihak baik pihak pengelola pesantren maupun pemerintah untuk mengadakan latihan-latiahan kepada santri ataupun pengelola dalam mengembangkan keterampilan dan kewirausahaan.

Perlunya pemerintah menyediakan pendampingan kepada pengelola pesantren dalam memberikan bantuan seperti usaha jahit menjahit agar usaha ini dapat dijalankan dan dikembangkan, begitupun juga dengan usaha-usaha lainnya.

\section{UCAPAN TERIMA KASIH}

Mengiringi selesainya tulisan ini, penulis mengucapkan terimakasih yang sebesar-besarnya kepada Bapak Kepala Balai Penelitian dan Pengembangan Agama Makassar yang telah memberikan kesempatan melakukan penelitian ini, juga kepada para informan peneliti yang telah membantu penulis dalam memberikan data-data terkait substansi penelitian, serta teman-teman peneliti yang aktif berdiskusi dengan penulis dalam memberikan masukan konsktruktif terhadap penelitian yang dilaksanakan.

\section{DAFTAR PUSTAKA}

Abd.Muin, dkk. 2007. Pesantren dan Pengembangan Ekonomi Umat. Jakarta. Cv.Prasasti.

Ahmad Nunu, dkk. 2010. Otoritas Pesantren dan Perubahan Sosial. Jakarta. Puslitbang Pendidikan Agama dan Keagamaan.

Daulay, Haidar Putra. 2012. Pendidikan Islam dalam Sistem Pendidikan Nasionalndi Indonesia. Jakarta. Kencana Prenada Media Group.

Muhamad. 2008. Metodologi Penelitian Ekonomi Islam: Pendekatan Kuantitatif. Jakarta. Rajagrafindo Persada.

Mulkhan, Abdul Munir. 2003. Moral Politik Santri: Agama dan Pembelaan Kaum Tertindas. Jakarta. Erlangga.

Peraturan Menteri Agama Nomor 13 tahun 2014 tentang Pendidikan Keagamaan Islam.

Peraturan Pemerintah Nomor 55 tahun 2007 tentang Pendidikan Agama dan Pendidikan Keagamaan

Pusat Pengkajian dan Pengembangan Ekonomi Islam (P3EI) Universitas Islam Indonesia Yogyakarta. 2008. Ekonomi Islam. Jakarta. Rajagrafindo Persada.

Qomar Mujamil. 2005. Pesantren: Dari Transformasi Metodologi Menuju Demokratisasi Institusi. Jakarta. Erlangga.

Supriyanto. Et all. 2011.Sejarah Pondok Pesantre di Sulawesi Tenggara. Kerjasama Lembaga Pengkajian Islam dengan Kanwil Kementerian Agama Provinsi Sulawesi Tenggara. 